\title{
Green Concrete: Environment Friendly Solution
}

\author{
Gomasa Ramesh
}

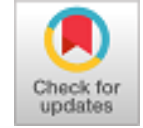

Abstract: Green concrete is a type of concrete. It is a sustainable material used for the construction of reinforced concrete structures. Green concrete is different compared to normal concrete. Nowadays, it plays a very good role in the construction of structures. It is subjected to very low energy consumption and low resource consumption. Green concrete is a very good material for sustainable development. Concrete is made from the replacement of substituent ingredients such as cement and aggregates. In this waste materials such as agricultural or industrial wastes are placed during manufacture to produce a new concrete. Green concrete is popular worldwide due to its extraordinary properties and applications. This paper mainly deals with the importance of green concrete and its applications, advantages, and disadvantages. The results are varying for based on different structures. So, we can get all characteristics and properties of concrete structures and know their strength.

Keywords: Green concrete, sustainable material, Recycled aggregate.

\section{INTRODUCTION}

Green concrete is a good material for construction and sustainable material. It is first used in Denmark. Concrete is made with concrete waste. Green concrete is a good material used in construction, which does not produce any harmful agents to the atmosphere and plays a good role in the eco-friendly construction of buildings, structures, etc. The concrete is made from cement, sand, gravel, and fly ash. These are mixed with water to form a good bonding material. The difference between normal concrete and green concrete is environmentally friendly, and reuse and reconstruction materials are made from waste materials. Normal concrete is not an environmentally friendly material. Green concrete can be used for any structure easily. Normal concrete is subjected to carbon emissions, but green concrete is not. It is the major advantage and reason for using green concrete over the world. This can be resistant to greenhouse gases and environmental pollutants etc. the main reason for existing green concrete is the reduction of carbon emissions in the environment. To free pollutants from the environment. It is one of the important technologies in concrete development in history. Because the world's landfills are rapidly filling up with trash that might be Recycled, it's past time to create and utilize sustainable building materials.

Building future sustainable green cities may be very difficult since cities must minimize their environmental

\footnotetext{
Manuscript received on 23 June 2021 | Revised Manuscript received on 28 July 2021 | Manuscript Accepted on 15 August 2021 | Manuscript published on 30 August 2021.

* Correspondence Author

Gomasa Ramesh*, Department of Civil Engineering, Warangal, Telangana, India. Email: rameshgomasa1@gmail.com

(C) The Authors. Published by Lattice Science Publication (LSP). This is an open access article under the CC-BY-NC-ND license (http://creativecommons.org/licenses/by-nc-nd/4.0/)
}

impact by using eco-friendly materials, conserving resources and energy.

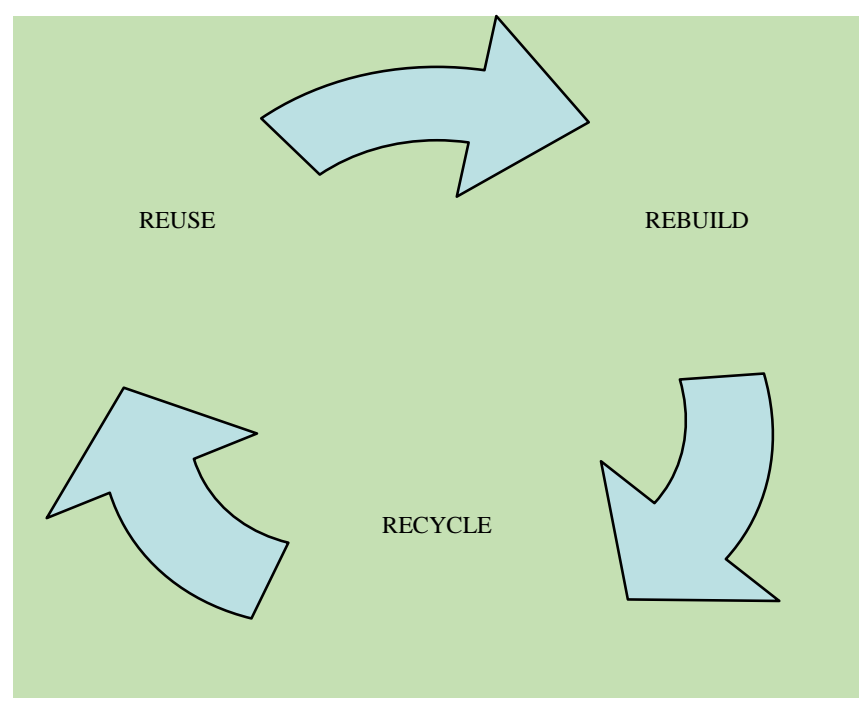

\section{Advantages}

Green concrete is the most recent advancement in construction technology, providing a long-term, environmentally friendly building material. Green concrete is a concept that involves partly or completely replacing cement with different elements that are either by-products of other materials' manufacturing processes or recovered trash. Green concrete has a lot of advantages compared to normal concrete. In this, we can discuss few important advantages. They are listed below.

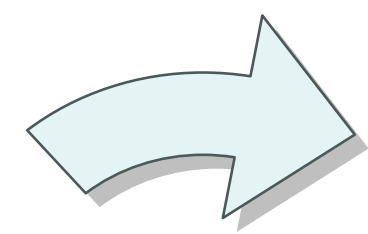

Economical

Self-compacting

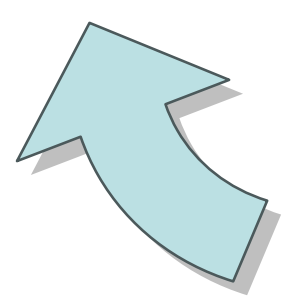

Sustainable

Material
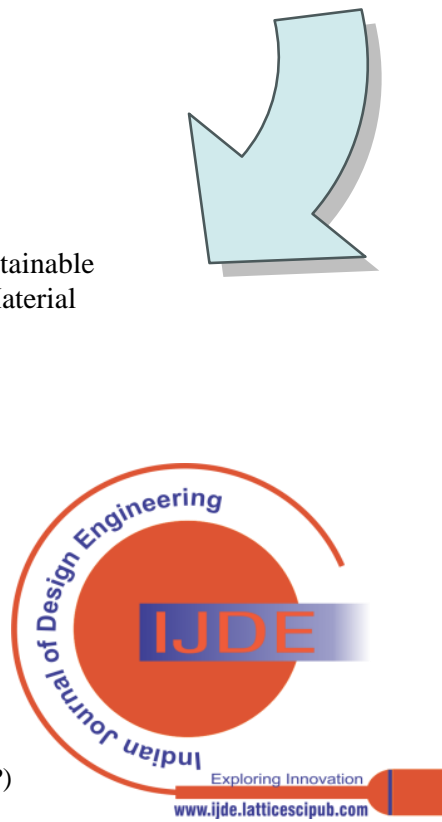


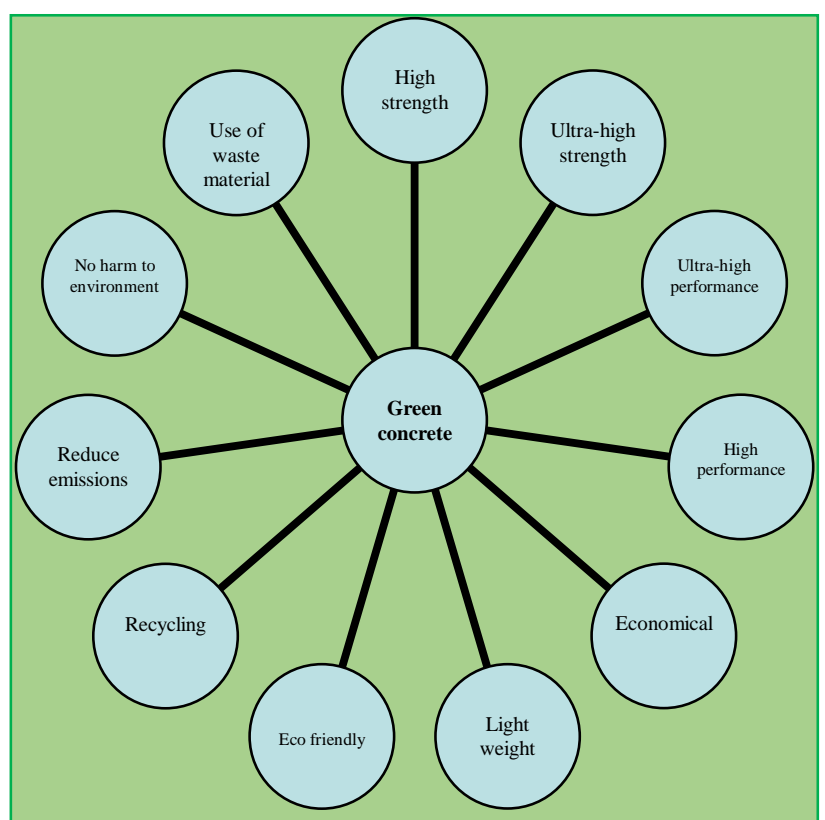

Dis Advantages

Every material has an advantage and some disadvantages too. Cement production emits approximately $8 \%-10 \% \mathrm{CO}_{2}$ and raises global temperatures. In this, green concrete is also subjected to some disadvantages. They are as follows;

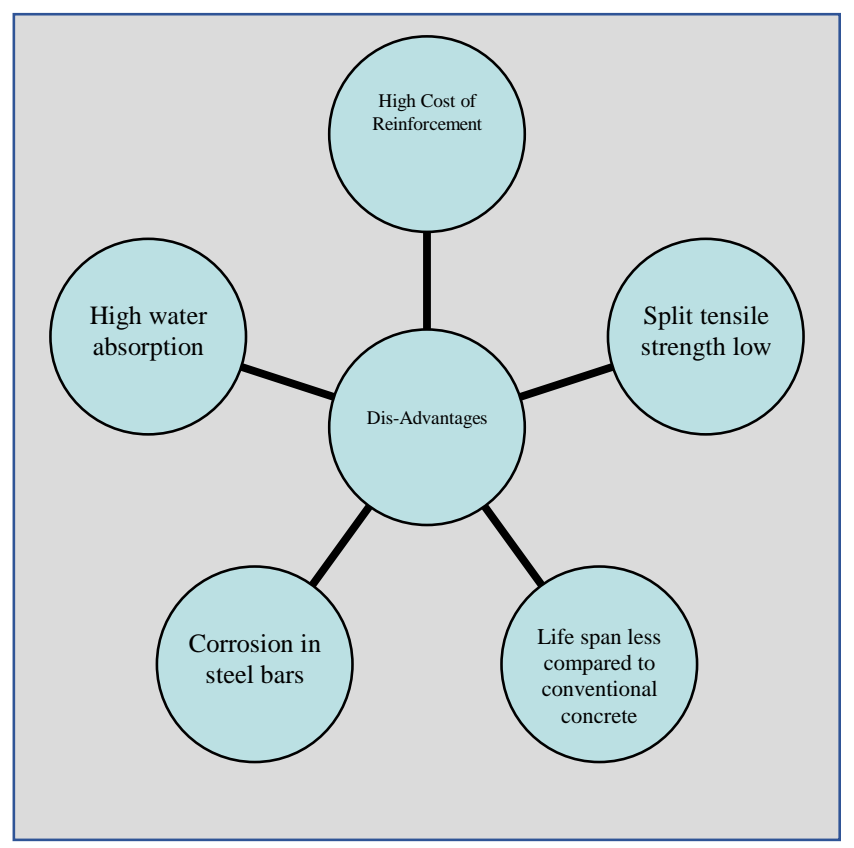

\section{Substitutes for production of green concrete}

In this, there are two types of wastes used for making green concrete. They are given below;

Wastes from industries

- Silica fume

- GGBS

- Fly ash

- Surkhi

Wastes from agriculture

- Rice Husk Ash

- Metakaolin

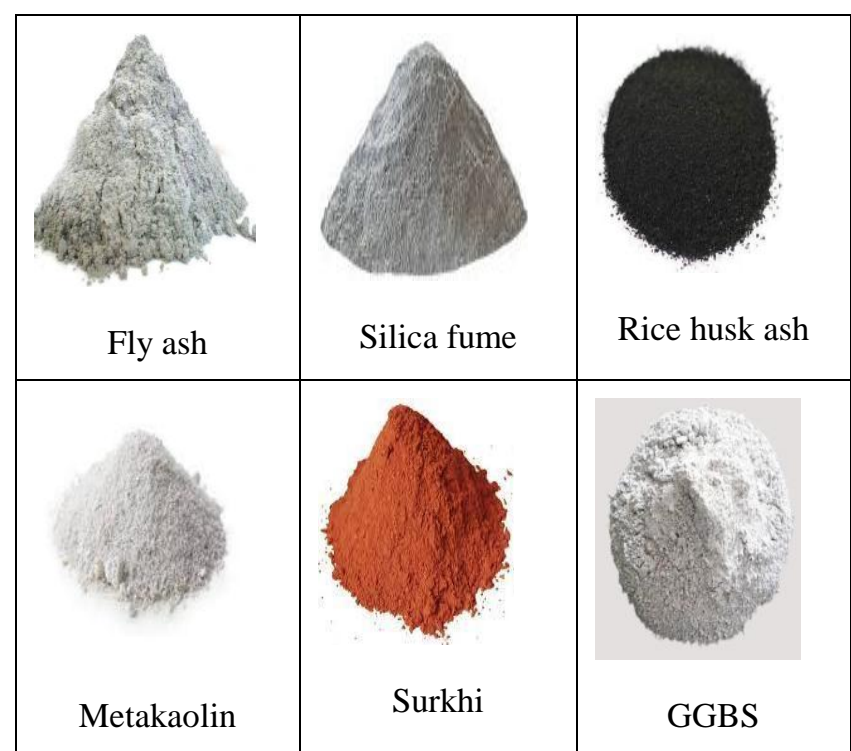

Fig.1 Substitutes of Green Concrete

\section{Recycled Aggregates}

The following are some of the green concrete materials. They are as follows;

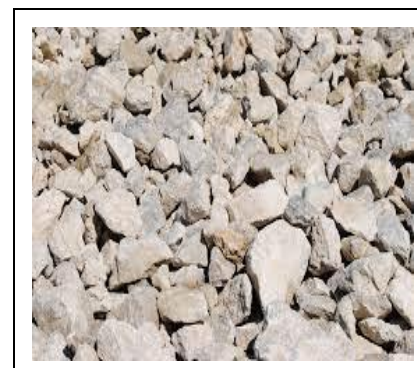

Recycled concrete material

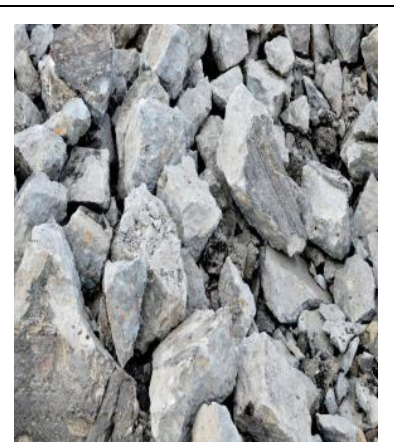

Demolished waste

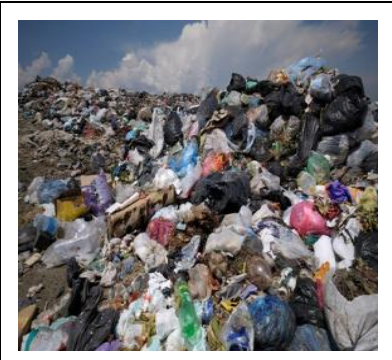

Plastic waste

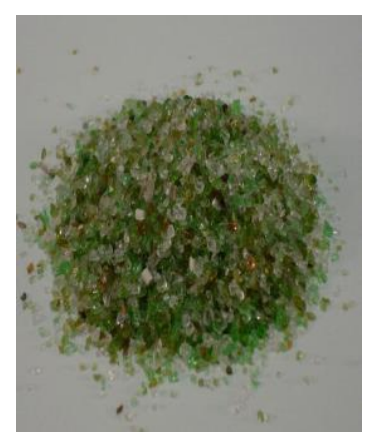

Recycled glass aggregates

Fig.2 Waste materials

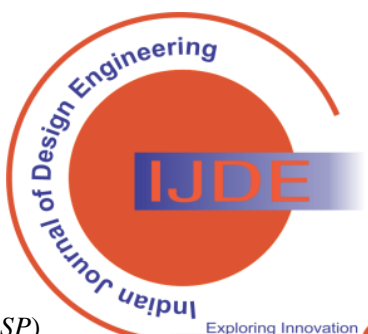

$$
\text { www.jide.latticescipub.com }
$$




\section{LITERATURE REVIEW}

\begin{tabular}{|c|c|c|}
\hline Author & Year & Research Findings \\
\hline $\begin{array}{c}\text { Karma } \\
\text { Wangchuk }\end{array}$ & 2013 & $\begin{array}{l}\text { In every kind of building, there are many options for material selection. Engineers and } \\
\text { architects are being encouraged to use more sustainable materials due to the } \\
\text { increasing interest in sustainable building. Green concrete, which is suitable for } \\
\text { long-term building, is distinguished by industrial wastes to minimize natural resource } \\
\text { and energy consumption and pollution of the environment. Green concrete is more } \\
\text { environmentally friendly since it replaces materials that would otherwise be used in } \\
\text { conventional concrete. }\end{array}$ \\
\hline Glavind & 2002 & $\begin{array}{l}\text { Denmark's commitment to decrease CO2 emissions by } 21 \% \text { below } 1990 \text { levels by } \\
\text { 2012, as promised at the Kyoto and Bonn Conferences, is dependent on cement and } \\
\text { concrete. It is also feasible to utilize leftover products while keeping a high level of } \\
\text { concrete quality, minimizing the need to dump these materials. To achieve } \\
\text { environmental benefits, it is necessary to consider the full life cycle of a concrete } \\
\text { building. This emphasizes the importance of working together as a team. The Center } \\
\text { for Green Concrete was established to accomplish this goal. For all stages of concrete } \\
\text { structure design, building, and usage, new technology is being created. So far, the } \\
\text { results show that the established environmental objectives will be met. }\end{array}$ \\
\hline Thomas & 2016 & $\begin{array}{l}\text { Due to the environmental issues caused by waste tyre rubber, new environmentally } \\
\text { friendly concretes such as rubberized concrete are being pushed forward. Thousands } \\
\text { of millions of tyres are abandoned, thrown away, or buried every year across the } \\
\text { globe, posing a significant environmental concern. The potential of waste tyre rubber } \\
\text { particles as a partial replacement for fine aggregates in standard and high strength } \\
\text { cement concrete and their abrasion resistance is investigated in this research. To } \\
\text { reinforce the findings of the experiments, statistical analysis was carried out. The } \\
\text { findings indicate that using tyre rubber particles in concrete may enhance its abrasion } \\
\text { resistance, allowing it to be used in pavements, floors, concrete roads, and other } \\
\text { applications where abrasive forces exist between surfaces and moving objects. }\end{array}$ \\
\hline Siddique & 2018 & $\begin{array}{l}\text { To accomplish sustainable building, it is critical to reuse waste resources for } \\
\text { construction materials. The use of waste materials as building materials helps } \\
\text { preserve the environment, but it also saves money. The strength and durability of } \\
\text { green concrete produced using SFS as a sand substitute are also discussed. SFS was } \\
\text { used to replace natural sand in concrete at weight replacement values of } 0,5,10,15 \text {, } \\
\text { and } 20 \% \text {. Strength improvements of up to } 26 \text { percent and } 12.87 \text { percent above control } \\
\text { concrete after } 28 \text { days, respectively. Similarly, SFS-treated concrete mixes had } \\
\text { reduced chloride ion penetration and improved salt scaling resistance by } 7.2-17.7 \% \\
\text { and 6.6-26.42 percent, respectively. }\end{array}$ \\
\hline Maraveas & 2020 & $\begin{array}{l}\text { The construction industry has many difficulties in contemporary times, mainly due to } \\
\text { rising urban populations and diminishing natural resources that enable the } \\
\text { manufacturing of building materials. The materials were chosen primarily based on } \\
\text { their popularity and widespread usage in contemporary building applications. } \\
\text { Furthermore, the emphasis of this study is on finding alternative methods to } \\
\text { developing sustainable building materials. }\end{array}$ \\
\hline
\end{tabular}

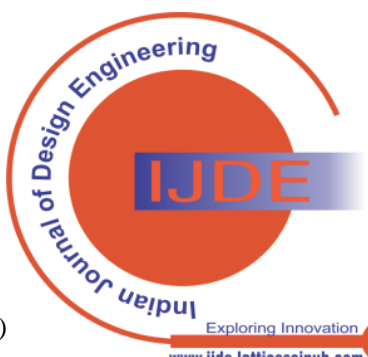




\begin{tabular}{|c|c|c|}
\hline Duxson & 2007 & $\begin{array}{l}\text { Inorganic polymers (also known as "geopolymers") are addressed in terms of their } \\
\text { potential role and drivers in the quest for more sustainable concrete industry. It is } \\
\text { generally acknowledged that several problems prevent broad use of geopolymer } \\
\text { technology. They were challenging to comply with. Work on addressing these } \\
\text { problems continues, with accelerated durability testing indicating that salt scaling and } \\
\text { freeze-thaw cycles can be overcome. Their detrimental impacts on concrete } \\
\text { performance are given special emphasis, implying that a better knowledge of geo } \\
\text { polymerization chemistry is required for the technology to be effectively } \\
\text { implemented. In contrast to Portland-based cement, the connection between CO2 } \\
\text { footprint and composition is calculated. }\end{array}$ \\
\hline Sadek & 2012 & $\begin{array}{l}\text { Population growth, urbanization, and industrialization all led to a rapid depletion of } \\
\text { natural resources and the production of significant trash. Unless they are shown to be } \\
\text { hazardous via testing, waste recycling in the concrete industry will result in greener } \\
\text { and more sustainable concrete. It provides a solution to the difficulties associated } \\
\text { with its disposal while also adding changed characteristics to the concrete. In general, } \\
\text { ACS-containing concrete performed better than concrete composed solely of natural } \\
\text { aggregates. Furthermore, using ACS in concrete with RCA reduced the detrimental } \\
\text { effects of RCA on concrete strength and durability without increasing the cement } \\
\text { amount. }\end{array}$ \\
\hline Liew & 2017 & $\begin{array}{l}\text { countries' aim to decrease greenhouse gas emissions, the need to conserve natural } \\
\text { resources, and limited landfill space has contributed to the rise in demand for green } \\
\text { concrete. Green concrete comes in a variety of forms. Cracking is just a few of the } \\
\text { many environmental, technical, and economic advantages of green concrete. These } \\
\text { features encourage quicker concrete production, shorter curing times, lower } \\
\text { construction costs. }\end{array}$ \\
\hline Kim Hung & 2016 & $\begin{array}{l}\text { The increasing use of concrete has resulted from the growing demand for buildings } \\
\text { throughout the globe. On the other hand, conventional concrete-making materials are } \\
\text { not completely environmentally friendly, prompting research into greener concrete } \\
\text { alternatives. Extensive study has been done to use agricultural waste materials. the } \\
\text { results show that such resources may be used in concrete. Reusing agricultural waste } \\
\text { materials in concrete may decrease reliance on traditional concrete-making resources } \\
\text { while also reducing environmental impact. Materials are conducted in this article to } \\
\text { evaluate the advantages and drawbacks of utilizing these materials. The use of } \\
\text { agricultural waste materials reduced certain concrete characteristics, effective } \\
\text { treatment techniques, and waste material selection would allow for concrete with } \\
\text { better performance. This paper's overview and discussion should offer fresh } \\
\text { information and understand a wider range of agricultural waste materials utilized to } \\
\text { make greener and more sustainable concrete. }\end{array}$ \\
\hline Golewski & 2018 & $\begin{array}{l}\text { Green buildings are now an essential component of ensuring sustainability, and } \\
\text { concrete composites containing FA may undoubtedly be incorporated in green } \\
\text { concrete. To minimize the environmental danger posed by FA waste disposal and } \\
\text { decrease cement use, effective marketing of green concrete that incorporates FA is } \\
\text { needed. The impact of age of concretes treated with FA addition on the parameters } \\
\text { studied was evaluated during the testing. The tests were carried out after } 3,7,28,90 \text {, } \\
180 \text {, and } 365 \text { days of cure. Stress intensity variables have been found to have crucial } \\
\text { levels. The characteristics of composites containing FA are affected by the concrete's } \\
\text { age at the time of testing. }\end{array}$ \\
\hline
\end{tabular}

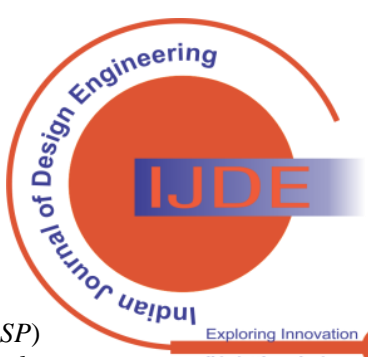




\section{APPLICATIONS}
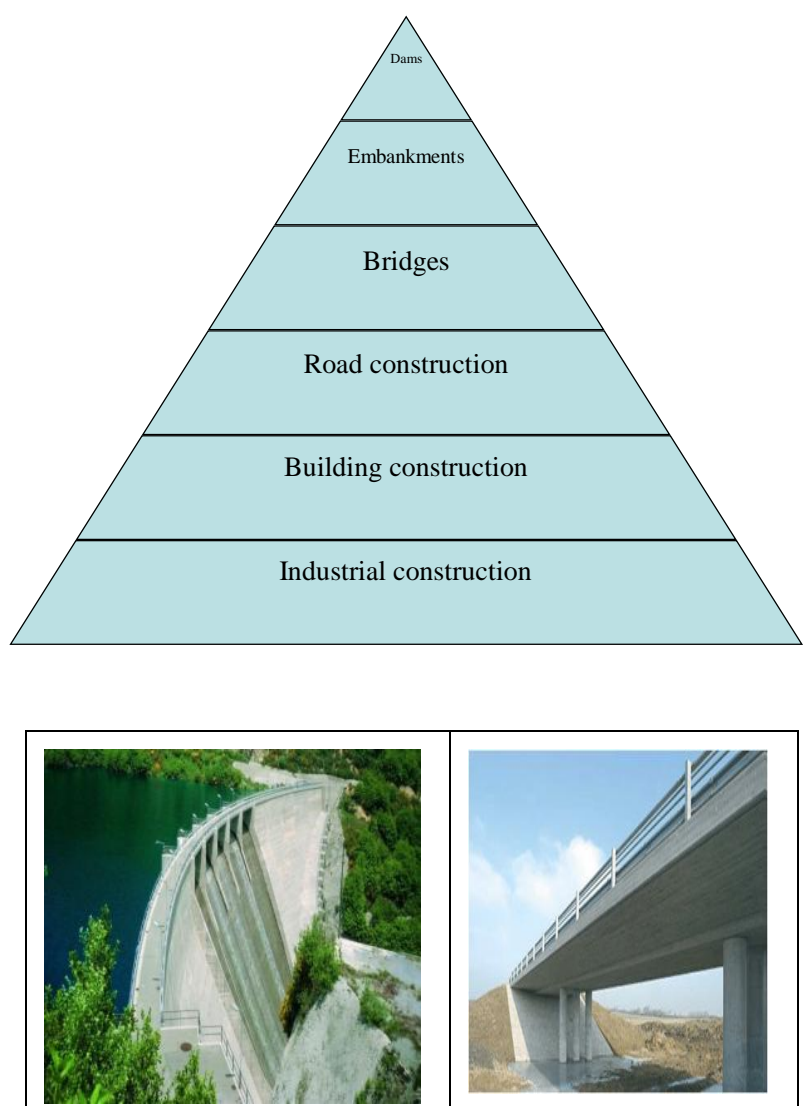

Green concrete dam

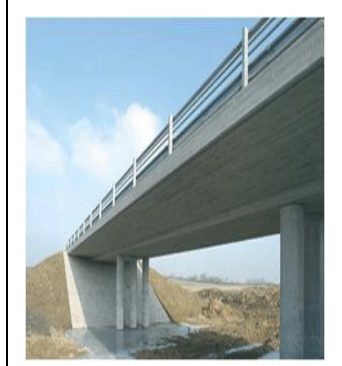

Green concrete bridges

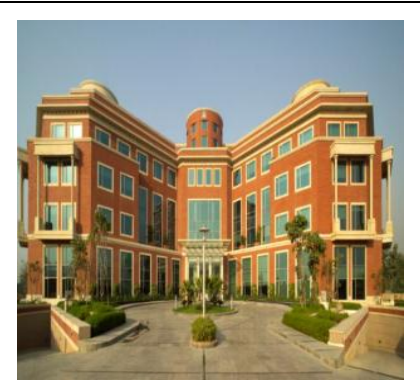

Green concrete building

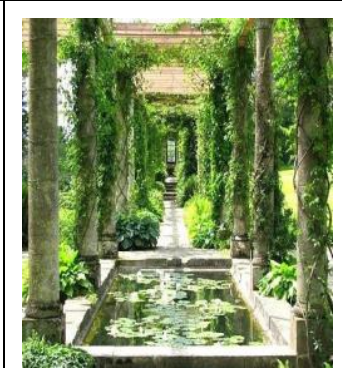

Green concrete column

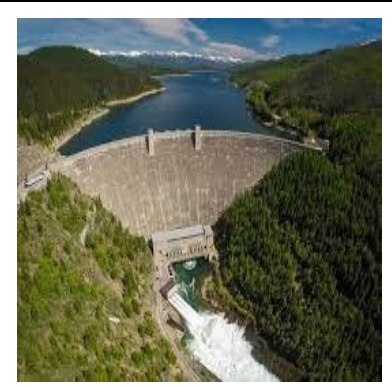

Hungry horse dam

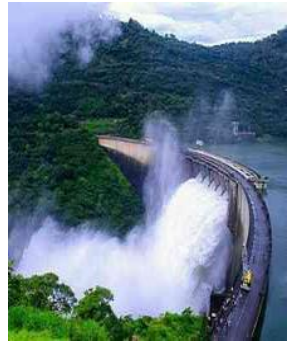

Rihand dam

\section{GREEN CONCRETE IN THE CONSTRUCTION OF STRUCTURES AND SUITABILITY}

Reasons for the need for green concrete

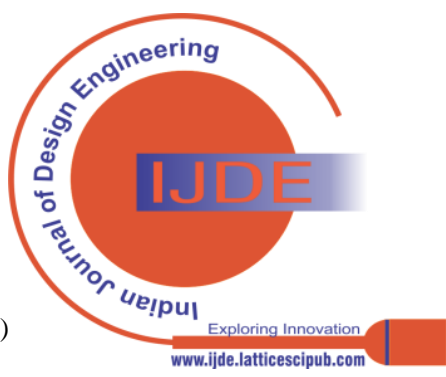

Reduce dead load on the structure

$>$ Reduce overloading in the structure

$>$ Good resistance to fire and insulation

$>$ Reduction of carbon dioxide around 30\%

waste usage increase

$>$ Less maintenance and repairs

\section{MATERIAL PROPERTIES}

The performance and cost of the components would be used to determine which materials to use in the concrete mix. Following are some of the material properties of green concrete.

\section{Cement}

\begin{tabular}{|c|c|c|}
\hline S.No. & Test & Results \\
\hline 1 & Specific gravity & 3.10 \\
\hline 2 & Fineness & 4.0 \\
\hline
\end{tabular}

\section{Fine aggregate}

\begin{tabular}{|c|c|c|}
\hline S.No. & Test & Results \\
\hline 1 & Specific gravity & 2.5 \\
\hline 2 & Fineness & 3.2 \\
\hline 3 & Water absorption & 0.5 \\
\hline
\end{tabular}

\section{Coarse aggregate}

\begin{tabular}{|c|c|c|}
\hline S.No. & Test & Results \\
\hline 1 & Specific gravity & 2.5 \\
\hline 2 & Aggregate crushing & 14 \\
\hline 3 & Aggregate impact & 6.0 \\
\hline
\end{tabular}


Green Concrete: Environment Friendly Solution

\section{Recycled aggregate}

\begin{tabular}{|c|c|c|}
\hline S.No. & Test & Results \\
\hline 1 & Specific gravity & 2.70 \\
\hline 2 & Water absorption & 0.15 \\
\hline
\end{tabular}

Fly ash

\begin{tabular}{|c|c|c|}
\hline S.No. & Test & Results \\
\hline 1 & Specific gravity & 2.01 \\
\hline 2 & Fineness & 2.7 \\
\hline
\end{tabular}

\section{Air content}

\begin{tabular}{|c|c|c|}
\hline S.No. & Max. size of aggregate (mm) & Air content \\
\hline 1 & 10 & 1.4 \\
\hline 2 & 20 & 1.0 \\
\hline 3 & 40 & 0.7 \\
\hline
\end{tabular}

\section{Water content}

\begin{tabular}{|c|c|c|c|}
\hline S.No. & $\begin{array}{c}\text { Max. size } \\
\text { aggregate } \\
\text { (mm) }\end{array}$ & $\begin{array}{c}\text { Water content } \\
\text { per } \mathbf{~ m}^{\mathbf{3}} \text { of } \\
\text { concrete } \mathbf{( K g )}\end{array}$ & Sand (\%) \\
\hline 1 & 10 & 201 & 39 \\
\hline 2 & 20 & 180 & 32 \\
\hline 3 & 40 & 160 & 29 \\
\hline
\end{tabular}

\section{TESTS \& RESULTS}

\section{Compressive strength}

This test is conducted on concrete to know the load-carrying capacity of concrete without any cracks and deflections in the concrete. A cube test is conducted to know all about the characteristics of concrete. The strength of concrete varies from 20 to 30 maps depending on the structural strength will vary. Compression leans towards reducing the size. Size of cubes $15 \times 15 \times 15 \mathrm{~cm}$ is used.

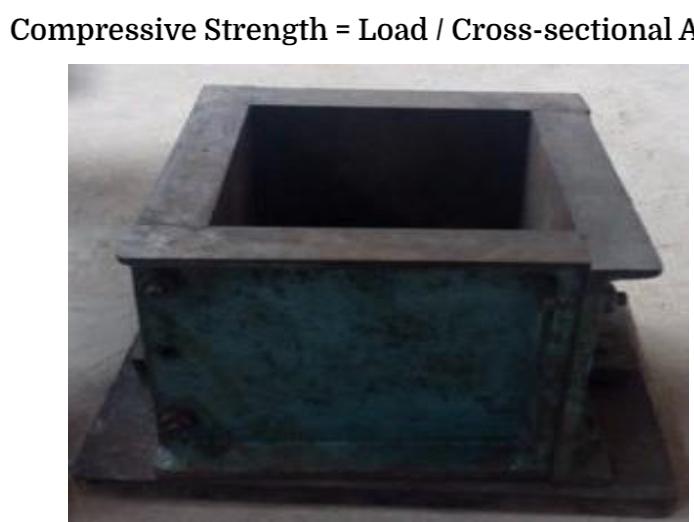

Fig.3 Mould

\begin{tabular}{|c|c|}
\hline Strength (\%) & Age (days) \\
\hline 15 & 1 \\
\hline 40 & 3 \\
\hline 66 & 7 \\
\hline 90 & 14 \\
\hline 99 & 28 \\
\hline
\end{tabular}

\section{Compressive strength of concrete}

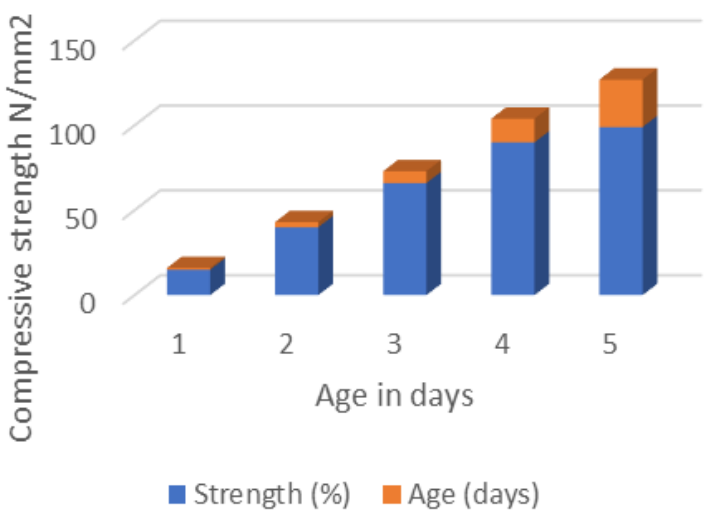

\section{Tensile strength}

A tensile strength test is conducted to know the ability of the material to withstand the tensile loads. So, tensile strength tests are used to elongation of materials and their properties as well.

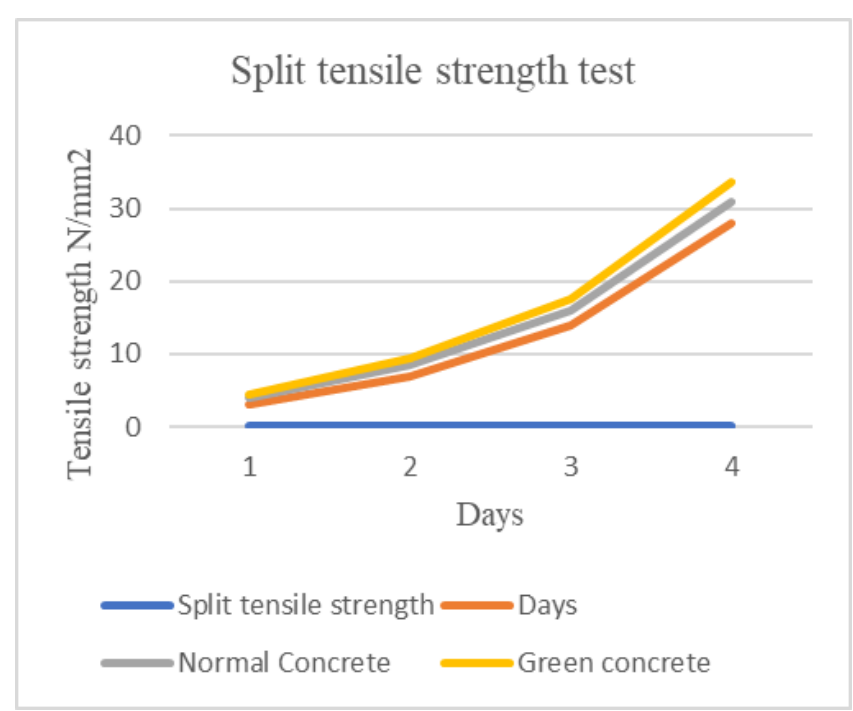

\section{CONCLUSION}

Green concrete is a good material for concrete structures. It gives very good strength and durability to the concrete structures.

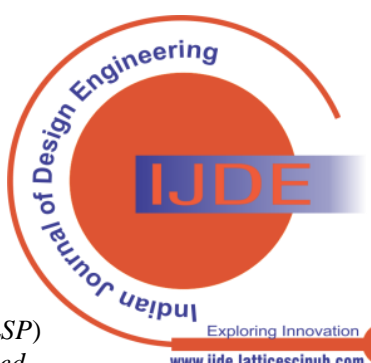


Compared to conventional concrete, it gives good workability under any condition to the concrete structures. Nowadays, a lot of research is going on concrete to increase its durability and strength aspects and decrease and avoid unnecessary problems to the environment. Now we got an excellent bonding material in the form of green concrete. The color of concrete is green, and it represents eco-friendliness to the environment. My final words to the conclusion of green concrete are reuse, recycle, rebuild the concrete structures.

\section{REFERENCES}

1. Wangchuk, Karma, Kelzang Tsheten, and Kinga Yezer. "Green concrete for sustainable construction." (2013).

2. Suhendro, Bambang. "Toward green concrete for better sustainable environment.” Procedia Engineering 95 (2014): 305-320. [CrossRef]

3. Siddique, Rafat, Gurpreet Singh, and Malkit Singh. "Recycle option for metallurgical by-product (Spent Foundry Sand) in green concrete for sustainable construction.” Journal of Cleaner Production 172 (2018): 1111-1120. [CrossRef]

4. Duxson, Peter, et al. "The role of inorganic polymer technology in the development of 'green concrete'." cement and concrete research 37.12 (2007): 1590-1597. [CrossRef]

5. Sadek, Dina M., and Mohamed M. El-Attar. "Development of high-performance green concrete using demolition and industrial wastes for sustainable construction.” Journal of American Science 8.4 (2012): 120-131.

6. Liew, K. M., A. O. Sojobi, and L. W. Zhang. "Green concrete: Prospects and challenges." Construction and building materials 156 (2017): 1063-1095. [CrossRef]

7. Mo, Kim Hung, et al. "Green concrete partially comprised of farming waste residues: a review." Journal of Cleaner Production 117 (2016): 122-138. [CrossRef]

8. Golewski, Grzegorz Ludwik. "Green concrete composite incorporating fly ash with high strength and fracture toughness." Journal of Cleaner Production 172 (2018): 218-226. [CrossRef]

9. Vishwakarma, Vinita, and D. Ramachandran. "Green Concrete mix using solid waste and nanoparticles as alternatives-A review." Construction and Building Materials 162 (2018): 96-103. [CrossRef]

10. Ramesh,. "Self-Compacting Concrete: A Review." Indian Journal of Structure Engineering (IJSE) Volume-1 Issue-2 (2021): 9-12. [CrossRef]

11. Glavind, M., and C. Munch-Petersen. "Green concrete-a life cycle approach." Challenges of Concrete Construction: Volume 5, Sustainable Concrete Construction: Proceedings of the International Conference held at the University of Dundee, Scotland, UK on 9-11 September 2002. Thomas Telford Publishing, 2002. [CrossRef]

12. Radonjanin, Vlastimir, et al. "Green recycled aggregate concrete.” Construction and Building Materials 47 (2013): 1503-1511. [CrossRef]

13. Ramesh,. "Geopolymer Concrete: A Review." Indian Journal of Structure Engineering (IJSE) Volume-1 Issue-2 (2021): 5-8. [CrossRef]

14. Thomas, Blessen Skariah, et al. "Abrasion resistance of sustainable green concrete containing waste tire rubber particles." Construction and Building Materials 124 (2016): 906-909. [CrossRef]

15. Ramesh G. Design and Analysis of Multistoried Structure by Using STAAD Pro. Indian Journal of Engineering, 2021, 18(49), 191-197.

16. Altwair, Nurdeen M., and Shahid Kabir. "Green concrete structures by replacing cement with pozzolanic materials to reduce greenhouse gas emissions for sustainable environment." 6th International Engineering and Construction Conference, Cairo, Egypt. 2010.

17. Srinath, Ramya,. "Repair, rehabilitation and retrofitting of reinforced concrete structures by using non-destructive testing methods." Materials Today: Proceedings (2021).

18. Maraveas, Chrysanthos. "Production of sustainable construction materials using agro-wastes.” Materials 13.2 (2020): 262. [CrossRef]

19. Khan, Sarah, et al. "Experimental design of green concrete and assessing its suitability as a sustainable building material." Materials Today: Proceedings 26 (2020): 1126-1130. [CrossRef]

20. Shahria Alam, M., Emma Slater, and A. H. M. Muntasir Billah. "Green concrete made with RCA and FRP scrap aggregate: fresh and hardened properties." Journal of materials in civil engineering 25.12 (2013): 1783-1794. [CrossRef]

21. Reiner, Mark, Stephan A. Durham, and Kevin L. Rens. "Development and analysis of high-performance green concrete in the urban infrastructure." International Journal of Sustainable Engineering 3.3 (2010): 198-210. [CrossRef]

22. Vishwakarma, Vinita, and Sudha Uthaman. "Environmental impact of sustainable green concrete." Smart Nanoconcretes and Cement-Based Materials. Elsevier, 2020. 241-255. [CrossRef]

23. Elchalakani, Mohamed, Hakan Basarir, and Ali Karrech. "Green concrete with high-volume fly ash and slag with recycled aggregate and recycled water to build future sustainable cities." Journal of Materials in Civil Engineering 29.2 (2017): 04016219. [CrossRef]

24. Srinath,. "Earthquake Resistant of RCC Structures." Lateral Part 1 (1893): 2007.

25. Altwair, N. M., and Shahid Kabir. "Reducing environmental impacts through green concrete technology." 3rd Technology and Innovation for Sustainable Development International Conference, Khon Kaen University, Thailand. 2010.

26. Sheshu Kumar. "Importance of Dynamic Analysis for RCC Structures." International Journal for Modern Trends in Science and Technology 6.8 (2020): 271-276. [CrossRef]

27. Müller, Harald S., et al. "Design and properties of sustainable concrete.” Procedia Engineering 95 (2014): 290-304. [CrossRef]

28. Ramya,. "Health Monitoring of Structures by Using Non-Destructive Testing Methods." International Journal of Advances in Engineering and Management (IJAEM) Volume 2: 652-654.

29. Gursel, Aysegul Petek, Helena Maryman, and Claudia Ostertag. "A life-cycle approach to environmental, mechanical, and durability properties of "green" concrete mixes with rice husk ash." Journal of Cleaner Production 112 (2016): 823-836. [CrossRef]

30. Vamshi Krishna. "Mechanical properties of sustainable concrete by using RHA and hydrated lime." Materials Today: Proceedings (2021).

31. Rahimi, Saman, et al. "Sustainable approach for recycling waste tire rubber and polyethylene terephthalate (PET) to produce green concrete with resistance against sulfuric acid attack." Journal of Cleaner Production 126 (2016): 166-177. [CrossRef]

32. Ramesh,. "Study on Mechanical Properties of Polyurethane Foam Concrete." Indian Journal of Structure Engineering (IJSE) Volume-1 Issue-1, May (2021): 1-3. [CrossRef]

33. Mohammadhosseini, Hossein, et al. "Waste metalized film food packaging as low cost and ecofriendly fibrous materials in the production of sustainable and green concrete composites." Journal of Cleaner Production 258 (2020): 120726. [CrossRef]

34. Ramesh G. Design and Analysis of Residential Building using STAAD-Pro. Indian Journal of Engineering, 2021, 18(49), 185-190.

35. Vairagade, Vikrant S., D. K. Parbat, and S. A. Dhale. "Fly ash as sustainable material for green concrete-a state of art.” Int. J. Res. Eng. Sci. Technol 1 (2015): 17-24.

36. Sheshu Kumar, "Importance of Dynamic Analysis for RCC Structures", International Journal for Modern Trends in Science and Technology, Volume 6(8), pp: 271-276, 2020. [CrossRef]

37. Mohammadhosseini, Hossein, et al. "Durability performance of green concrete composites containing waste carpet fibers and palm oil fuel ash.” Journal of cleaner production 144 (2017): 448-458. [CrossRef]

38. Ramesh,. "Low Carbon Buildings for Sustainable Constructions." Indian Journal of Structure Engineering (IJSE) Volume-1 Issue-2, November (2021): 1-4. [CrossRef]

39. Jyothi Kiran, "A Study on Geopolymer Concrete", International Journal of Innovative Research in Science, Engineering and Technology, Volume10, Issue 4, April 2021, pp:3818-3824.

40. Awwad, Elie, et al. "Sustainable construction material using hemp fibers-preliminary study." Proceedings of the Second International Conference on Sustainable Construction Materials and Technologies. Ancona, Italy: Università Politecnica delle. 2010.

41. Ramesh,. "Pervious Concrete: A Review." Indian Journal of Structure Engineering (IJSE) Volume-1 Issue-1 (2021): 4-8. [CrossRef]

42. Marathe, Shriram, I. R. Mithanthaya, and Sahithya Shetty. "Strength behaviour of masonry blocks produced using green concrete." Sustainable Construction and Building Materials. Springer, Singapore, 2019. 33-40. [CrossRef]

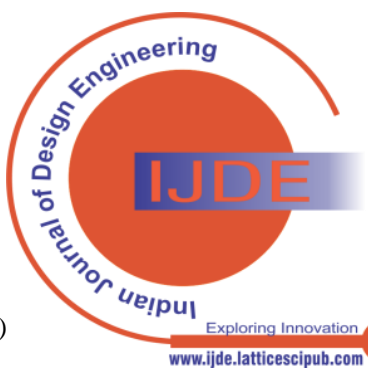


43. Ramesh, Gomasa. "Transparent Concrete: A Review." (2001).

44. Kiruthika, C., S. Lavanya Prabha, and M. Neelamegam. "Different aspects of polyester polymer concrete for sustainable construction.” Materials Today: Proceedings 43 (2021): 1622-1625. [CrossRef]

45. Pooja,. "Experimental Study on Mechanical Properties of Geopolymer Concrete by using Fly Ash and RHA.” International Journal for Modern Trends in Science and Technology 7.02 (2021).

46. Prakash, A. R., (2021). Shear Behavior of Hybrid Fiber Reinforced Concrete. Concrete", International, 7(02), 79-82. [CrossRef]

47. Dr Annamalai Rangasamy Prakash. "Repair, Rehabilitation and Retrofitting of Reinforced Concrete Structures." 2278-0181.

48. Sravani, Sriramoju,. "Study on Percentage Replacement of Cement by Glass powder for M20 Grade Concrete." International Journal for Modern Trends in Science and Technology 7.02 (2021): 129-132.

49. Kumar, Palakurthi Manoj,. "Evaluation of Different Tests and their Comparisons by Combining Cement with Various Binders.” International Journal for Modern Trends in Science and Technology 7.03 (2021): 119-122.

50. Krishna, B. V., (2021). Effect of Geo-Activator on Strength and Durability Properties of Geopolymer Concrete. International Journal for Modern Trends in Science and Technology, 7(03), 123-126.

51. Ramesh,. "A Review on Sustainable Transportation."

52. Zhukov, A. D., Bobrova, Y., Zelenshchikov, D., Mustafaev, R., \& Khimich, A. (2014). Insulation systems and green sustainable construction. In Advanced Materials Research (Vol. 1025, pp. 1031-1034). Trans Tech Publications Ltd. [CrossRef]

53. Saipriya, "An Experimental Observe of Replacing Conventional Coarse Aggregate with Electronic Waste for M45 Grade concrete Using Natural Sand", International Journal for Modern Trends in Science and Technology, Vol. 07, Issue 03, March 2021, pp.: 115-118. [CrossRef]

54. Anil, "A Study on Underwater Concrete Structures", International Journal of Innovative Research in Science, Engineering and Technology, Volume 10, Issue 4, April 2021, pp:3832-3839.

55. Valipour, Mahdi, Mohammad Shekarchi, and Mahdi Arezoumandi. "Chlorine diffusion resistivity of sustainable green concrete in harsh marine environments." Journal of Cleaner Production 142 (2017): 4092-4100. [CrossRef]

56. Kumar, "Investigation of the Strength and Durability of Partially Replacing Cement with GGBS and Alccofine", International Journal of Innovative Research in Science, Engineering and Technology, Volume 10, Issue 4, April 2021, pp: 3789-3795.

57. Van den Heede, Philip, and Nele De Belie. "Sustainability assessment of potentially 'green'concrete types using life cycle assessment." Sustainable and nonconventional construction materials using inorganic bonded fiber composites. Woodhead Publishing, 2017. 235-263. [CrossRef]

58. Kwong, Tang Hing, Flora Anak Albert Daud, and Chai Teck Jung "Sustainable Green Concrete by using Biomass Aggregate." Journal of Advanced Research in Applied Sciences and Engineering Technology 18.1 (2020): 31-37. [CrossRef]

59. Colangelo, Francesco, et al. "Life cycle assessment (LCA) of different kinds of concrete containing waste for sustainable construction.” Buildings 8.5 (2018): 70. [CrossRef]

60. Jain, Neeraj, Mridul Garg, and A. K. Minocha. "Green concrete from sustainable recycled coarse aggregates: mechanical and durability properties.” Journal of Waste Management 2015 (2015). [CrossRef]

\section{AUTHORS PROFILE}

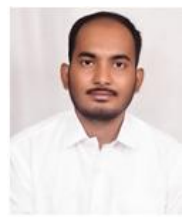

Mr. Gomasa Ramesh, M. Tech Civil Engineering. His research interests include structural health monitoring, Non-destructive evaluation, Repair and rehabilitation of concrete structures, Damage assessment of reinforced concrete structures, and Special concrete materials.

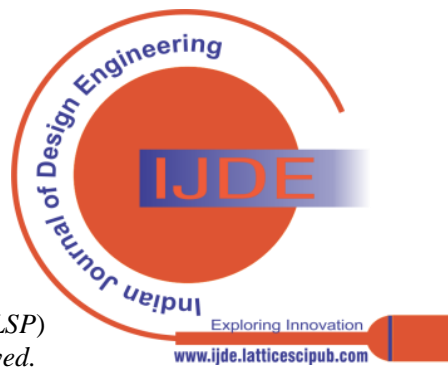

